Atmos. Chem. Phys., 18, 16385-16398, 2018

https://doi.org/10.5194/acp-18-16385-2018

(C) Author(s) 2018. This work is distributed under

the Creative Commons Attribution 4.0 License.

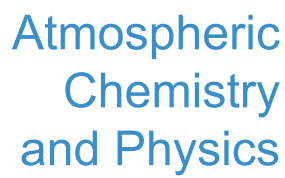

(c) (i)

\title{
The vertical variability of ammonia in urban Beijing, China
}

\author{
Yangyang Zhang ${ }^{1}$, Aohan Tang ${ }^{1}$, Dandan Wang ${ }^{1}$, Qingqing Wang ${ }^{2}$, Katie Benedict ${ }^{3}$, Lin Zhang ${ }^{4}$, Duanyang Liu ${ }^{5}$, \\ Yi Li ${ }^{6}$, Jeffrey L. Collett Jr. ${ }^{3}$, Yele Sun ${ }^{2,7}$, and Xuejun Liu ${ }^{1}$ \\ ${ }^{1}$ Beijing Key Laboratory of Farmland Soil Pollution Prevention and Remediation, College of Resources and Environmental \\ Sciences, China Agricultural University, Beijing 100193, China \\ ${ }^{2}$ State Key Laboratory of Atmospheric Boundary Layer Physics and Atmospheric Chemistry, Institute of Atmospheric \\ Physics, Chinese Academy of Sciences, Beijing 100029, China \\ ${ }^{3}$ Department of Atmospheric Science, Colorado State University, Fort Collins, CO 80523, USA \\ ${ }^{4}$ Laboratory for Climate and Ocean-Atmosphere Studies, Department of Atmospheric and Oceanic Sciences, \\ School of Physics, Peking University, Beijing 100871, China \\ 5 Jiangsu Meteorological Observatory, Nanjing 210008, China \\ ${ }^{6}$ Sunset CES Inc., Beaverton, OR 97008, USA \\ ${ }^{7}$ Collaborative Innovation Center on Forecast and Evaluation of Meteorological Disasters, Nanjing University \\ of Information Science \& Technology, Nanjing 210044, China
}

Correspondence: Aohan Tang (aohantang@cau.edu.cn), Yele Sun (sunyele@ mail.iap.ac.cn), and

Xuejun Liu (liu310@cau.edu.cn)

Received: 24 July 2018 - Discussion started: 3 September 2018

Revised: 30 October 2018 - Accepted: 5 November 2018 - Published: 19 November 2018

\begin{abstract}
Weekly vertical profiles of ammonia $\left(\mathrm{NH}_{3}\right)$ were measured at 16 heights on the Beijing $325 \mathrm{~m}$ meteorological tower for 1 year from March 2016 to March 2017. The average $\mathrm{NH}_{3}$ concentrations exceeded $4 \mu \mathrm{g} \mathrm{m}^{-3}$ at all heights with an overall average $( \pm 1 \sigma)$ value of $13.3( \pm 4.8) \mu \mathrm{g} \mathrm{m}^{-3}$. The highest $\mathrm{NH}_{3}$ concentrations along the vertical profiles mostly occurred from 32 to $63 \mathrm{~m}$, decreasing both towards the surface and at higher altitudes. Significant decreases in $\mathrm{NH}_{3}$ concentrations were only found at the top two heights (280 and $320 \mathrm{~m}$ ). These results suggest an $\mathrm{NH}_{3}$ rich atmosphere during all seasons in urban Beijing, from the ground to at least $320 \mathrm{~m}$. The highest seasonal $\mathrm{NH}_{3}$ concentrations across the profile were observed in summer $\left(18.2 \mu \mathrm{g} \mathrm{m}^{-3}\right)$ with high temperature, followed by spring $\left(13.4 \mu \mathrm{g} \mathrm{m}^{-3}\right)$, autumn $\left(12.1 \mu \mathrm{g} \mathrm{m}^{-3}\right)$ and winter $\left(8.3 \mu \mathrm{g} \mathrm{m}^{-3}\right)$. A significant vertical variation in the $\mathrm{NH}_{3}$ concentration was only found in summer. Source region analyses suggest that air masses from intensive agricultural regions to the south contribute most to the high $\mathrm{NH}_{3}$ concentrations in Beijing. Local sources such as traffic emissions also appear to be important contributors to atmospheric $\mathrm{NH}_{3}$ in this urban environment.
\end{abstract}

\section{Introduction}

Ammonia $\left(\mathrm{NH}_{3}\right)$ has long been recognized as an important form of reactive nitrogen $(\mathrm{Nr})$ in the atmospheric environment, playing a key role in biogeochemical cycles from atmospheric chemical processes to deposition and in subsequent environmental impacts (e.g., air pollution, reduced biodiversity, acidification and eutrophication) (Fowler et al., 2009; Sutton et al., 2008). $\mathrm{NH}_{3}$ reacts with nitric and sulfuric acids in air, forming secondary inorganic aerosols (e.g., $\left.\mathrm{NH}_{4} \mathrm{NO}_{3},\left(\mathrm{NH}_{4}\right)_{2} \mathrm{SO}_{4}\right)$ with long atmospheric lifetimes that can transport these species far from sources and contribute $40 \%-57 \%$ of the fine particle matter in megacities (Fowler et al., 2009; Huang et al., 2014; Yang et al., 2011). Therefore, $\mathrm{NH}_{3}$ has received increasing attention in air pollution research (Wang et al., 2015). In addition to agriculture, which is considered the largest global $\mathrm{NH}_{3}$ source, emissions from biomass burning, industry, vehicles and other sources (Galloway et al., 2003; Sutton et al., 2008; Erisman et al., 2008; Sun et al., 2016, 2017) can also be significant.

In China, annual $\mathrm{NH}_{3}$ emissions were approximately 2 and 3 times higher than European and US emissions, respectively, over the period from 1990 to 2005 (Reis et al., 2009; 
Kang et al., 2016; Zhao and Wang, 1994; Klimont, 2001; EMEP, 2018; USEPA, 2018), and were estimated to be 14.6 $\mathrm{Tg} \mathrm{N} \mathrm{yr}^{-1}$ in 2010 (Liu et al., 2013) and $15.6 \mathrm{Tg} \mathrm{N} \mathrm{yr}^{-1}$ in 2015 (Zhang et al., 2017). Such high emissions, in addition to the important role $\mathrm{NH}_{3}$ plays in degrading air quality, makes $\mathrm{NH}_{3}$ a key target to curb serious air pollution in Chinese urban areas (Fu et al., 2017; Chang et al., 2016; Ye et al., 2011; Wang et al., 2011). Some studies have indicated that reducing $\mathrm{NH}_{3}$ concentrations could be an effective method for alleviating secondary inorganic $\mathrm{PM}_{2.5}$ pollution in China (Gu et al., 2014; Wang et al., 2015; Wu et al., 2016; $\mathrm{Xu}$ et al., 2017). However, $\mathrm{NH}_{3}$ has received less attention from the government than $\mathrm{SO}_{2}$ and $\mathrm{NO}_{x}$, which have been controlled since 2005 and were effectively reduced during the 12th Five-Year Plan period (2011-2015) (Fu et al., 2017). Currently there are strong arguments regarding the role of regional transport in contributing to haze pollution in China (Guo et al., 2014; Li et al., 2015), especially for severe haze episodes occurring during stagnant meteorological conditions with a shallow boundary layer (Sun et al., 2014; Zheng et al., 2015; Quan et al., 2013). The vertical characterization of air pollutant concentration profiles may be helpful for elucidating factors contributing to the formation and transport of regional haze events (Quan et al., 2013; Tang et al., 2015; Wiegner et al., 2006). Many studies have been conducted to improve our understanding of temporal and spatial concentration dynamics of atmospheric $\mathrm{NH}_{3}$ and how they relate to underlying factors (e.g., emission intensity and meteorological conditions) and air quality (Yamamoto et al., 1988, 1995; Bari et al., 2003; Vogt et al., 2005; Lee et al., 1999). However, such studies in China have generally focused on the spatial distribution of $\mathrm{NH}_{3}$ near the ground (Ianniello et al., 2010; Wu et al., 2009; Meng et al., 2011; Xu et al., 2015), whereas the vertical characterization of $\mathrm{NH}_{3}$ concentrations has been very limited.

$\mathrm{NH}_{3}$ mixing ratios may vary significantly as a function of height, as $\mathrm{NH}_{3}$ is a trace gas with both point and nonpoint sources, and it also has a tendency to deposit rapidly to surfaces. In urban locations, like Beijing, where $\mathrm{NH}_{3}$ is a key contributor to fine particle formation, local sources (e.g., traffic) emit at the surface and are then mixed through the boundary layer, while $\mathrm{NH}_{3}$ transported from agricultural sources outside the city is presumably already mixed through the boundary layer. The influence of these behaviors may be reflected in the vertical $\mathrm{NH}_{3}$ concentration gradients measured within the city. For example, dominant local surface traffic emissions might give rise to a profile that peaks near the surface, while $\mathrm{NH}_{3}$ transported into the urban area may be uniformly mixed in the vertical or even decline near the surface due to loss by dry deposition. Of course these patterns are expected to be further affected by sinks, including surface deposition as well as by the fine particle formation of ammonium salts. $\mathrm{NH}_{3}$ vertical distribution measurements are also useful for advancing satellite retrievals, which offer a great potential for understanding the global distribution of gaseous $\mathrm{NH}_{3}$ (Shephard and Cady-Pereira, 2015; Sun et al., 2015; Van Damme et al., 2015).

To our knowledge there are few studies reporting longterm observations of the vertical distributions of $\mathrm{NH}_{3}$ in the lowest few hundred meters of the atmosphere, including measurements at the BAO tower in the USA ( $\mathrm{Li}$ et al., 2017; Tevlin et al., 2017) and the CESAR site in the Netherlands (Dammers et al., 2017). Li et al. (2017) analyzed vertical $\mathrm{NH}_{3}$ concentration profiles at the BAO tower in Colorado, USA, reporting the minimum concentration at the top of the tower, which slowly increased towards a peak concentration at $\sim 10 \mathrm{~m}$ before a large reduction in concentration was found at $1 \mathrm{~m}$. The site was influenced by the transport of high $\mathrm{NH}_{3}$ concentrations from large animal feeding operations to the northeast. Using higher time resolution measurements at the BAO tower, Tevlin et al. (2017) pointed out that the surface can act as an occasional $\mathrm{NH}_{3}$ sink as well as a source. The CESAR study in the Netherlands showed that vertical profile differences were mainly due to local and regional transport influences (Dammers et al., 2017). Because the BAO and CESAR tower sites are both located in suburban areas with low aerosol mass loadings, observed vertical profiles of aerosol and gas species (Öztürk et al., 2013; VandenBoer et al., 2013; Riedel et al., 2013) could be substantially different from those in megacities in China. Zhou et al. (2017) measured vertical concentration profiles of $\mathrm{NH}_{3}$ and 7 other air pollutants at 10 heights $(8,15,47,80,120$, $160,200,240,280$ and $320 \mathrm{~m}$ ) in urban Beijing, finding that $\mathrm{NH}_{3}$ concentrations peaked at $160 \mathrm{~m}$. However, only one vertical profile was measured and may not adequately represent typical conditions. Until now, long-term monitoring of vertical $\mathrm{NH}_{3}$ concentration profiles has not been carried out in China.

Here, we report a 1-year field campaign on the Beijing $325 \mathrm{~m}$ meteorological tower to investigate vertical $\mathrm{NH}_{3}$ concentration profiles and consider how temporal variations may relate to urban emission sources, meteorological factors and air transport from more distant sources. Study findings are relevant for our understanding of precursor $\mathrm{NH}_{3}$ distributions and the role of $\mathrm{NH}_{3}$ in the formation of severe aerosol pollution in China; furthermore, they will provide benchmarks to assist in meeting air quality goals and policy needs in future.

\section{Materials and methods}

\subsection{Site description}

The sampling site is located at the State Key Laboratory of Atmospheric Boundary Layer Physics and Atmospheric Chemistry (LAPC), Institute of Atmospheric Physics (IAP), Chinese Academy of Sciences (CAS) in urban Beijing $\left(39^{\circ} 58^{\prime} \mathrm{N}, 116^{\circ} 22^{\prime} \mathrm{E}\right.$; Fig. 1). The site is approximately $0.8 \mathrm{~km}$ north of the Third Ring Road, $1.3 \mathrm{~km}$ south of the Fourth Ring Road and $0.2 \mathrm{~km}$ west of the Beijing- 
(a)

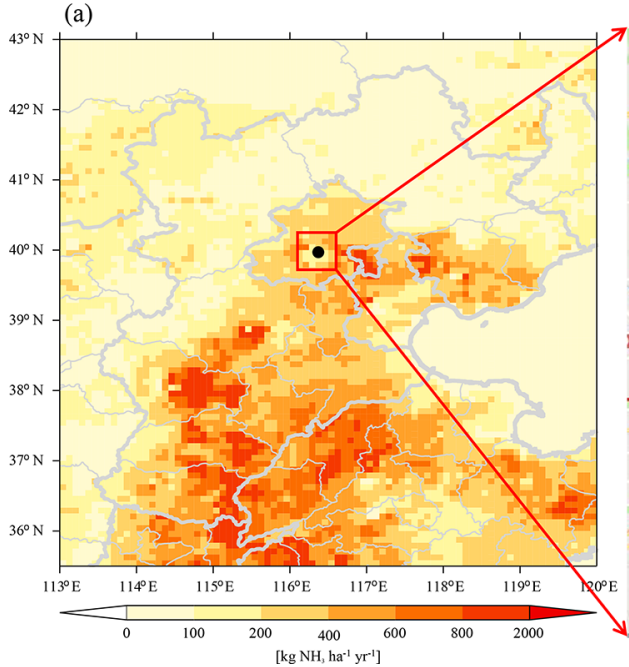

(b)

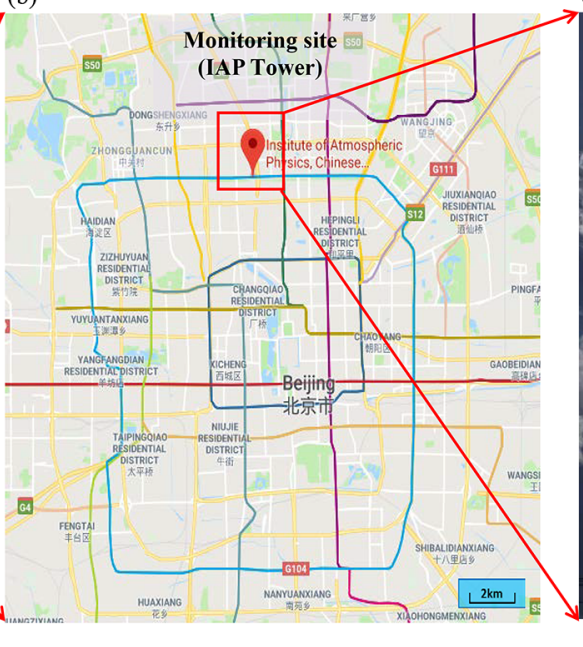

(c)

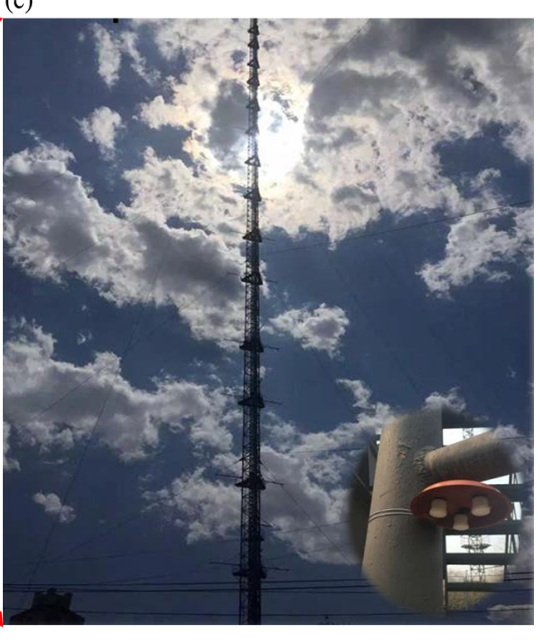

Figure 1. (a) Modeled $\mathrm{NH}_{3}$ emissions distribution $\left(0.1^{\circ}, \sim 10 \mathrm{~km}\right)$ over the North China Plain in 2015 including the location of the monitoring site shown as a black dot. $\mathrm{NH}_{3}$ emission estimates are from the inventory of Zhang et al. (2018) at a $0.1^{\circ}$ horizontal resolution. (b) Map of Beijing showing the location of the monitoring tower. (c) The $325 \mathrm{~m}$ meteorological tower and ALPHA passive samplers.

Tibet expressway, which are three transport arteries encircling Beijing, each with average traffic volumes of over 200000 vehicles day per day in 2016 (Beijing Transport Institute, 2017); therefore, this site represents a typical urban site that is mainly surrounded by residential areas.

\section{$2.2 \mathrm{NH}_{3}$ measurement}

From 16 March 2016 to 16 March 2017, weekly atmospheric $\mathrm{NH}_{3}$ samples were collected at 16 heights on the $325 \mathrm{~m}$ meteorological tower using ALPHA passive samplers (adapted low-cost high absorption, Centre for Ecology and Hydrology, Edinburgh, UK) except for a few samples with slightly different durations due to tower maintenance schedules. The samplers operate on the principle of diffusion using an acidcoated filter to capture the $\mathrm{NH}_{3}$. A PTFE (Teflon) membrane is placed directly at the mouth of the sampler, forming a quiescent boundary layer in front of the sample membrane. A stable, turbulent-free diffusion path length is achieved behind the membrane, whilst allowing gaseous $\mathrm{NH}_{3}$ to diffuse through for capture and minimizing the sampling of $\mathrm{NH}_{4}^{+}$ aerosol (Tang et al., 2014). $\mathrm{NH}_{3}$ was sampled at 2, 8, 15, $32,47,63,80,102,120,140,160,180,200,240,280$ and $320 \mathrm{~m}$ a.g.l. (above ground level). At each height, three ALPHA samplers were deployed under a PVC shelter to protect the samplers from rain and direct sunlight (shown in Fig. 1). $\mathrm{NH}_{3}$ samples were extracted with $10 \mathrm{~mL}$ high-purity water $(18.2 \mathrm{M} \Omega-\mathrm{cm})$ and analyzed using a continuous-flow analyzer (Seal AA3, Germany). Three field (travel) blanks were prepared for each batch of samples, which were analyzed together with the abovementioned samples, and used to blank correct sample results and determine the method detection limit (MDL) values. MDL was calculated using the follow- ing equation: MDL $\geq t \times S_{\mathrm{b}} \times \sqrt{\frac{N_{1}+N_{2}}{N_{1} \times N_{2}}}$, where the $t$ value is given at the $95 \%$ confidence level for the appropriate of degrees of freedom, $S_{\mathrm{b}}$ is the blank standard deviation, $N_{1}$ and $N_{2}$ are the number of sample measurements (single measurement, $\mathrm{N}_{1}=1$ ) and the number of analyzed blanks, respectively. From the field blanks, the MDL was calculated to be $0.31 \mu \mathrm{g} \mathrm{m}^{-3}$ for a 1-week ALPHA passive $\mathrm{NH}_{3}$ sample. All lab measurements were conducted in the Key Laboratory of Plant-Soil Interactions, Chinese Ministry of Education, China Agricultural University. More details regarding the passive samplers and the related laboratory preparation and analysis can be found in Xu et al. (2015).

\subsection{Meteorological data}

Meteorological parameters, including wind speed (WS), wind direction (WD), relative humidity (RH) and temperature $(T)$, were obtained at all sampling heights except $2 \mathrm{~m}$; the temperature was also not available at $8 \mathrm{~m}$. WS and WD were measured using four-cup anemometers (model O1OC, Met One Instruments), and $\mathrm{RH}$ and $T$ were measured using a $T / \mathrm{RH}$ sensor (model HC2-S3, ROTRONIC).

\subsection{Data analysis}

Repeated-measures analysis of variance (ANOVA) was used to test changes in the $\mathrm{NH}_{3}$ concentration along vertical profiles. When the ANOVA results were significant, the Tukey's honest significant difference (HSD) test was used to determine the significance of the difference between means with a significance level of $P<0.05$. The coefficient of determination was used to test the linear correlations with a significance level of $P<0.05$. All of the statistical analyses were 


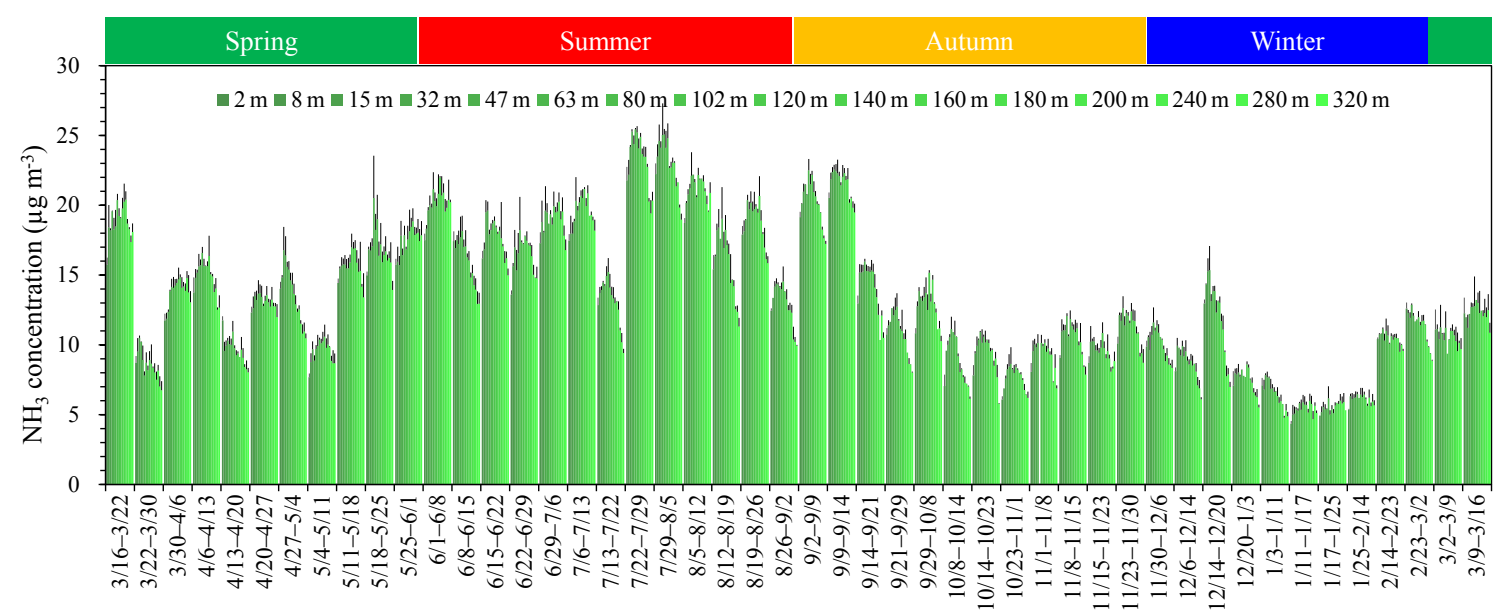

Figure 2. Time series of the vertical distribution of weekly atmospheric $\mathrm{NH}_{3}$ concentrations $( \pm 1 \sigma)$ in Beijing urban (16 March $2016-$ 16 March 2017).

conducted using SPSS version 23.0 (IBM Corp., Armonk, NY, USA).

Potential source contribution function analysis (PSCF) (Ashbaugh et al., 1985) of atmospheric $\mathrm{NH}_{3}$ was performed using MeteoInfo (TrajStat package) (Wang, 2014), where $72 \mathrm{~h}$ back trajectories arriving at the monitoring site (IAP tower) at each height were calculated every $3 \mathrm{~h}$ for the entire study period. The average $\mathrm{NH}_{3}$ concentration for each cluster was computed using the cluster statistics function. $\mathrm{NH}_{3}$ pathways could then be associated with the high concentration clusters. The number of trajectory segment endpoints falling in a grid cell $(i, j)$ is $n_{i j}$. The number of trajectory endpoints associated with the data with $\mathrm{NH}_{3}$ concentrations higher than an arbitrarily set criterion for each height during the four seasons (75th percentile for $\mathrm{NH}_{3}$ was set here) is $m_{i j}$ (Table $\mathrm{S} 1$ in the Supplement). The PSCF value for the $i j$ th cell is then calculated as $m_{i j} / n_{i j}$. A weighting function $W_{i j}$ was applied to reduce the uncertainties of small values of $n_{i j}$ (Polissar et al., 1999). Weighted PSCF values (WPSCF) were calculated by multiplying a particular $W_{i j}(\leq 1.00)$ if the total number of the endpoints for one grid cell was lower than 3 times the average of the endpoints per each cell. Higher WPSCF values indicate higher potential contributions of $\mathrm{NH}_{3}$ to the receptor site (IAP tower).

$W_{i j}=\left\{\begin{array}{ll}1.00 & 80<n_{i j} \\ 0.70 & 20<n_{i j} \leq 80 \\ 0.42 & 10<n_{i j} \leq 20 \\ 0.05 & n_{i j} \leq 10\end{array}\right\}$

\section{Results}

\subsection{Vertical profiles of $\mathrm{NH}_{3}$ concentrations}

The time series of weekly averages of $\mathrm{NH}_{3}$ concentrations from 16 March 2016 to 16 March 2017 are shown in Fig. 2.
The weekly $\mathrm{NH}_{3}$ concentration across all heights averaged $13.3 \pm 4.8 \mu^{-3} \mathrm{~m}^{-3}$ during the year-long study period. Individual weekly concentrations ranged from $4.4 \mu \mathrm{g} \mathrm{m}^{-3}$ at $2 \mathrm{~m}$ to $25.3 \mu \mathrm{g} \mathrm{m}^{-3}$ at $32 \mathrm{~m}$. Nearly all $(99.6 \%)$ of the weekly $\mathrm{NH}_{3}$ concentrations along the profile exceeded $5 \mu \mathrm{g} \mathrm{m}^{-3}$. Summer concentrations were generally the highest. Maximum $\mathrm{NH}_{3}$ concentrations mostly occurred between 32 and $63 \mathrm{~m}$, decreasing both towards the surface and the top of the tower. Minimum concentrations mostly occurred at 2 and $320 \mathrm{~m}$ (Fig. S1 in the Supplement). Significant differences of annual average $\mathrm{NH}_{3}$ concentrations across the vertical profile were only found between the "maximum concentration" height and the top two heights, i.e., 280 and $320 \mathrm{~m}$ (Fig. 3i). Even at $320 \mathrm{~m}$, the annual average $\mathrm{NH}_{3}$ concentration was still relatively high at $11.3 \mu \mathrm{g} \mathrm{m}^{-3}$ (Fig. 3i). During the whole observation period, the daily average boundary layer height was generally above $320 \mathrm{~m}$, indicating that a good portion of the sampling occurred within a well-mixed boundary layer (Fig. S2).

Seasonal vertical concentration profiles exhibited fairly similar shapes to the annual average profile, although there were some important differences in absolute concentration values and the magnitude of vertical gradients within the profiles (Fig. 3). The average $\mathrm{NH}_{3}$ concentration across the profile from high to low was observed in summer $\left(18.2 \mu \mathrm{g} \mathrm{m}^{-3}\right)$, spring $\left(13.4 \mu \mathrm{g} \mathrm{m}^{-3}\right)$, autumn $\left(12.1 \mu \mathrm{g} \mathrm{m}^{-3}\right)$ and winter $\left(8.3 \mu \mathrm{g} \mathrm{m}^{-3}\right)$. Proportional declines of the $\mathrm{NH}_{3}$ concentration from the peak to higher and lower elevations differed between seasons: the greatest proportional decline was seen in autumn (28.1\% decrease from 63 to $320 \mathrm{~m})$, followed by winter $(23.8 \%)$, summer $(20.5 \%)$ and spring $(15.8 \%)$ (Fig. S3). 

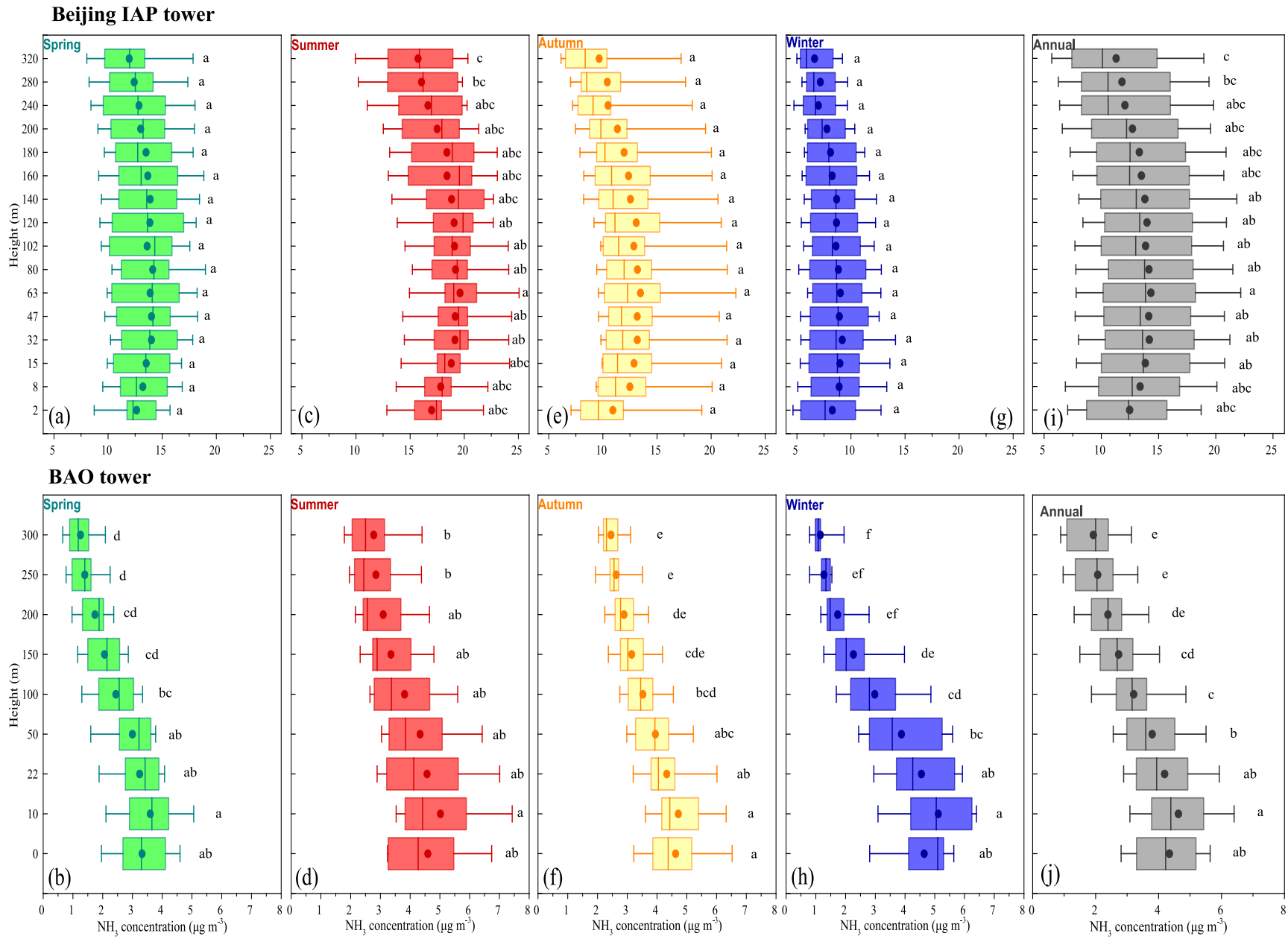

Figure 3. Comparison of seasonal vertical $\mathrm{NH}_{3}$ concentrations with the mean (dots), median, 10th, 25th, 75th and 90th percentiles of the $\mathrm{NH}_{3}$ concentrations of each height for the IAP tower (Beijing, this study; $\mathbf{a}, \mathbf{c}, \mathbf{e}, \mathbf{g}, \mathbf{i}$ ) and BAO tower (USA, Li et al., 2017; b, d, f, h, j). The lowercase letters next to the boxes denote the statistical difference in the $\mathrm{NH}_{3}$ concentration between all heights, where a one-way ANOVA was used, at the $p<0.05$ level.

\subsection{Meteorological variability}

Vertical $\mathrm{NH}_{3}$ concentration profiles varied substantially during the sampling period, along with vertical changes in meteorological parameters. Bivariate polar plots (Fig. 4) show that high $\mathrm{NH}_{3}$ concentrations below $47 \mathrm{~m}$ were mostly observed during periods with low wind speeds $\left(<4 \mathrm{~m} \mathrm{~s}^{-1}\right)$. As heights and associated wind speeds increased, the relationship between $\mathrm{NH}_{3}$ concentrations and wind speed weakened. For example, at $280 \mathrm{~m}$, the highest concentration was observed when the wind speed was also high (up to an average of $\sim 15 \mathrm{~m} \mathrm{~s}^{-1}$ ).

Wind direction also plays an important role in air pollution transport. Transport from the northwest was typically associated with low $\mathrm{NH}_{3}$ concentrations at all heights, consistent with the absence of large emissions sources in the mountains northwest of Beijing. It is noteworthy that high $\mathrm{NH}_{3}$ concentrations at near-surface heights $(8$ and $15 \mathrm{~m})$ always coincide with winds from the south, including the southeast and southwest directions. High $\mathrm{NH}_{3}$ concentrations appear to be associated with winds from the northeast from $32 \mathrm{~m}$ to $80 \mathrm{~m}$. Above $80 \mathrm{~m}$, winds from the south contribute more to high $\mathrm{NH}_{3}$ concentrations. Major regions of agricultural $\mathrm{NH}_{3}$ emissions are located south and east of Beijing.

To further investigate observed variability, we show the probability density function of $\mathrm{NH}_{3}$ concentrations in relation to the relative humidity $(\mathrm{RH})$ and temperature $(T)$ (Fig. 5). Clear positive relationships between $T$ and $\mathrm{NH}_{3}$ concentrations were found at all heights from low $\mathrm{RH}$ to high RH. When $T$ was low $\left(T<12^{\circ} \mathrm{C}\right)$, the $\mathrm{NH}_{3}$ concentration mostly fell below $10 \mu \mathrm{g} \mathrm{m}^{-3}$ under all RH conditions. The occurrence of high $\mathrm{NH}_{3}$ concentrations increased with $T>12^{\circ} \mathrm{C}$, which is not surprising given that agricultural $\mathrm{NH}_{3}$ emissions increase with $T$; furthermore, higher $T$ and lower $\mathrm{RH}$ also shift the equilibrium of the $\mathrm{NH}_{3}$ (gas) $+\mathrm{HNO}_{3}$ (gas) $\leftrightarrow \mathrm{NH}_{4} \mathrm{NO}_{3}$ (particulate) system to- 

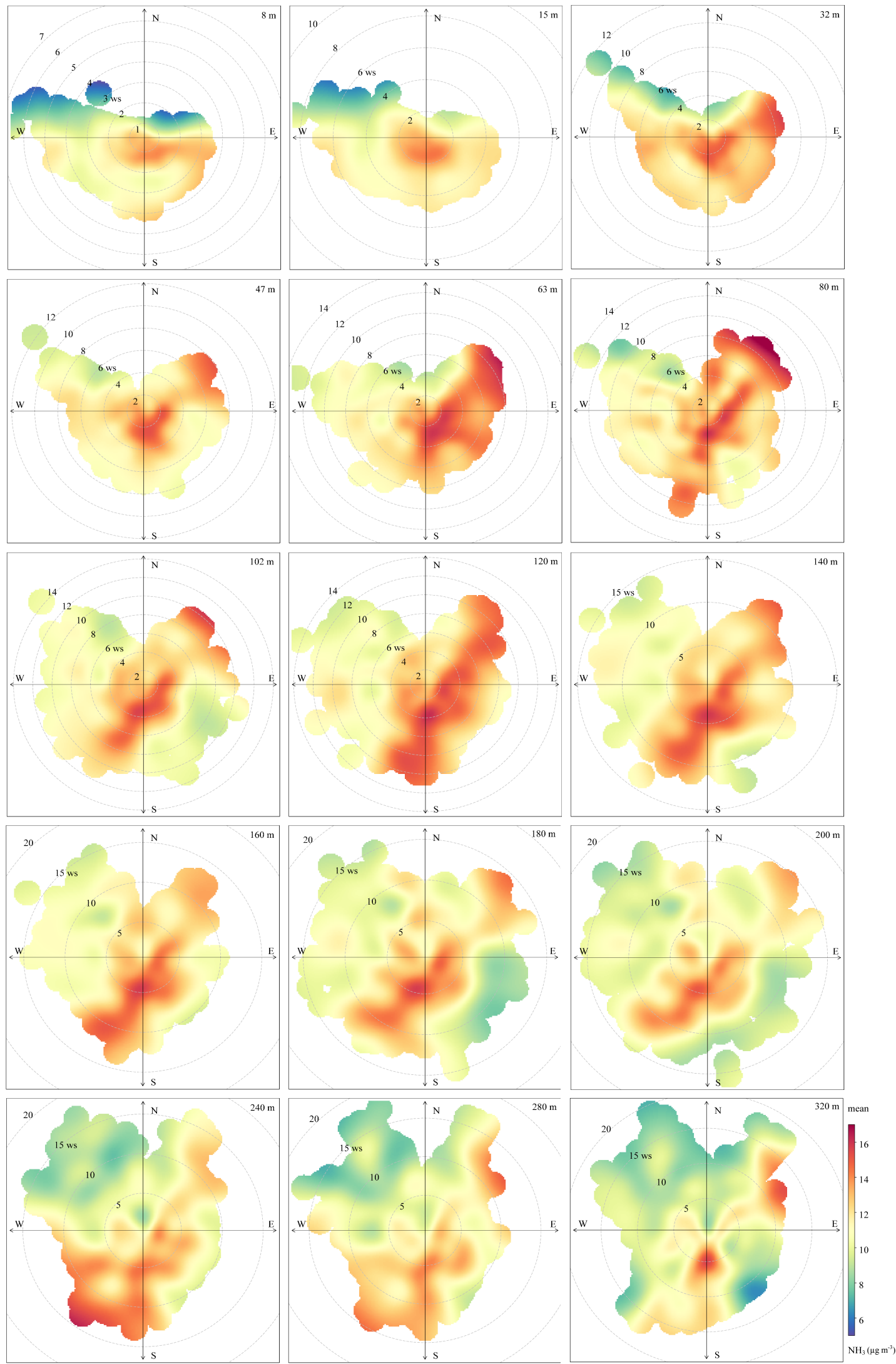

Figure 4. The frequency distributions of wind directions and $\mathrm{NH}_{3}$ concentration for all height during the observation period. Radial data are WS $\left(\mathrm{m} \mathrm{s}^{-1}\right)$ as a function of WD $\left(^{\circ}\right)$. The colors denote the $\mathrm{NH}_{3}$ concentrations $\left(\mu \mathrm{g} \mathrm{m}^{-3}\right)$. 


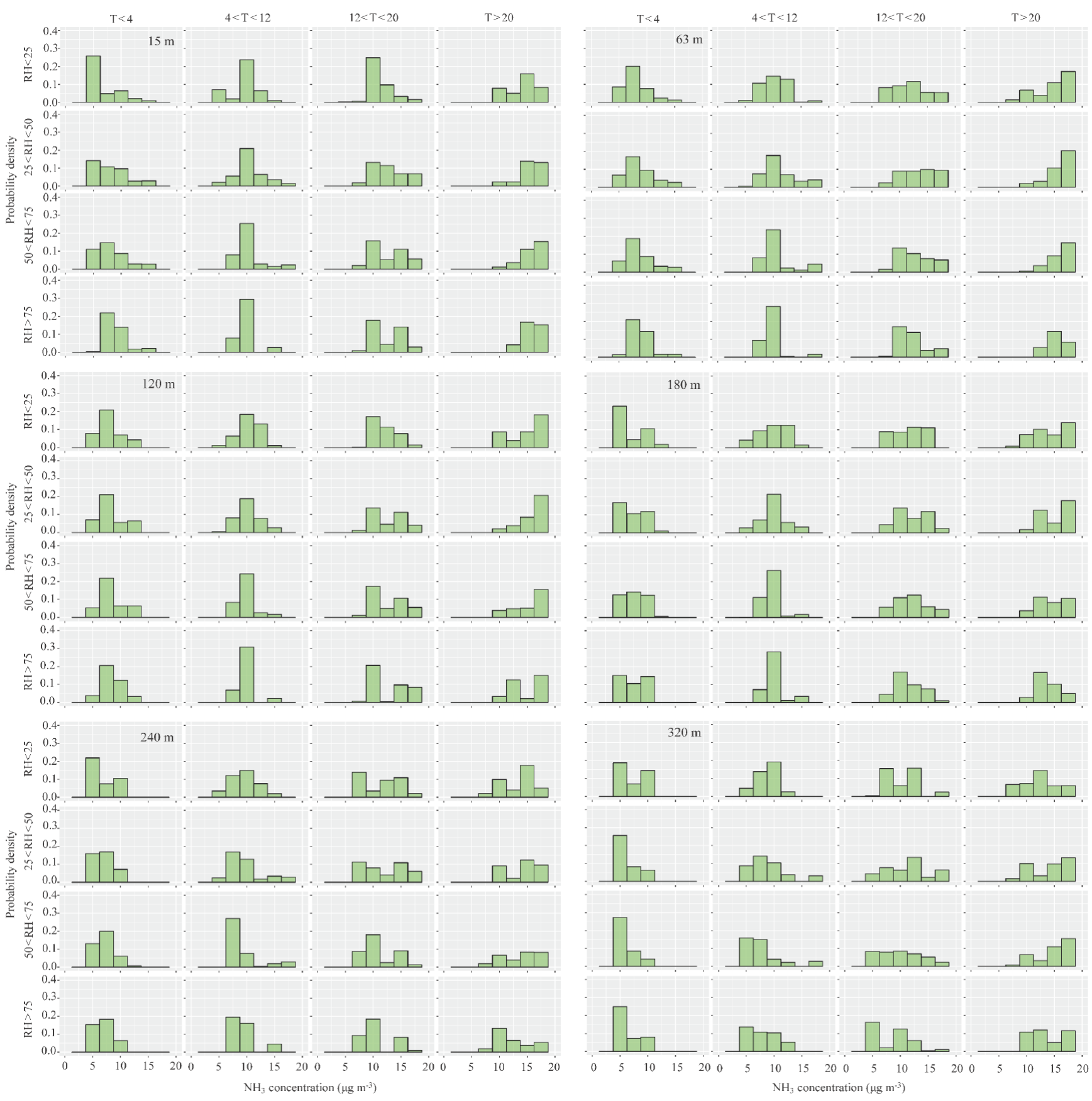

Figure 5. Probability density of $\mathrm{NH}_{3}$ concentrations $\left(\mu \mathrm{g} \mathrm{m}^{-3}\right)$ at different ranges of temperature ${ }^{1}\left({ }^{\circ} \mathrm{C}\right)$ and relative humidity ${ }^{2}(\%)$ for 14 heights. ${ }^{1}$ Temperature includes four subsets: $<4,4-12,12-20$ and $>20^{\circ} \mathrm{C} ;{ }^{2}$ relative humidity includes four subsets: $<25 \%, 25-50 \%$, $50-75 \%$ and $>75 \%$.

ward the gas phase. Statistically, a strong positive relationship was found between $\mathrm{NH}_{3}$ and $T$ at all heights from the surface to the top of the tower $\left(R^{2} \sim 0.6\right.$; Fig. S4); both the slope and the correlation coefficients were similar across all heights. Although, a positive correlation between $\mathrm{NH}_{3}$ and $\mathrm{RH}$ and a negative correlation between $\mathrm{NH}_{3}$ and WS were found, the correlation coefficients were quite low.

\subsection{Potential source analysis}

Analysis of the relationship between local wind direction and $\mathrm{NH}_{3}$ concentrations does not fully clarify the potential source regions contributing to observed $\mathrm{NH}_{3}$ at the sampling site (Fig. S6). Some seasonal variations were observed, i.e., the frequency of high $\mathrm{NH}_{3}$ concentrations were greater under southerly winds than northwesterly winds in the spring, the 

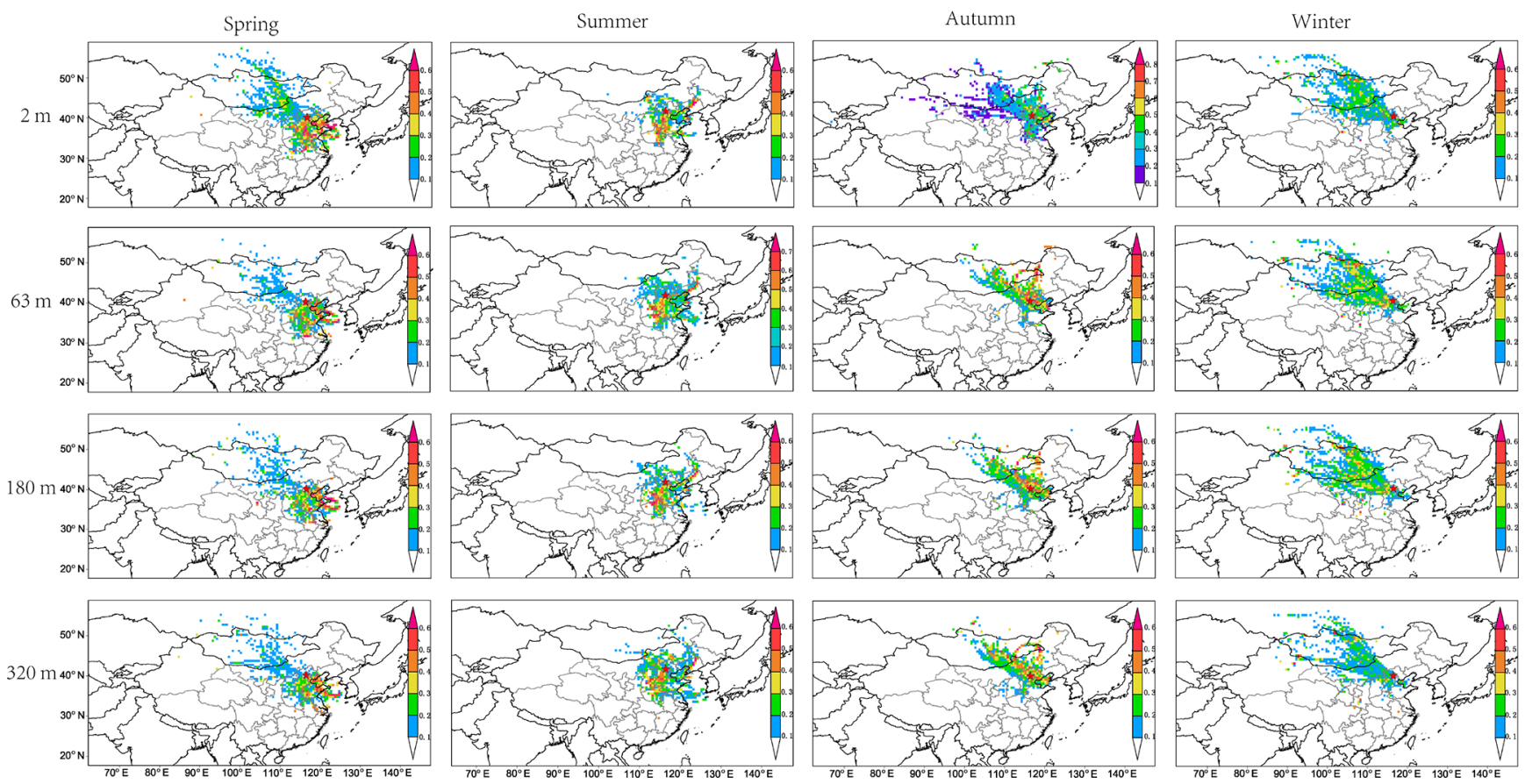

Figure 6. Weighted potential source contribution analysis (WPSCF) of atmospheric $\mathrm{NH}_{3}$ in Beijing from 16 March 2016 to 16 March 2017.

increased frequency of high $\mathrm{NH}_{3}$ concentrations were associated with southerly and easterly winds in the summer and autumn, and $\mathrm{NH}_{3}$ concentrations still exceeded $5 \mu \mathrm{g} \mathrm{m} \mathrm{m}^{-3}$ during winter with relatively frequent winds from the northwest.

To examine the relationship between air transport and $\mathrm{NH}_{3}$ concentrations more rigorously, weighted PSCF (WPSCF) during the four seasons were calculated for several measurement heights (2, 63, 180 and $320 \mathrm{~m}$ ) (Fig. 6). In summer, from the surface to the tower top, a strong influence from source areas to the south of Beijing was seen, coinciding with regions (e.g., Tianjin, Henan, Hebei and Shandong provinces) characterized by elevated anthropogenic emissions of $\mathrm{NH}_{3}$ (Fig. 1), largely from agricultural activities (Zhang et al., 2009; Gu et al., 2012). During summer, regions to the north and west of the monitoring site had low WPSCF values, whereas high WPSCF values to the south and southeast were common during spring. High WPSCF values were mainly located northwest and southeast of Beijing in autumn, while their WPSCF values were typically lower in winter than during other seasons.

It is important to remember that aerosol-gas partitioning can also strongly influence measured $\mathrm{NH}_{3}$ concentrations. To investigate seasonal phase changes between $\mathrm{NH}_{3}$ and $\mathrm{NH}_{4}^{+}$, we define the $\mathrm{NH}_{3}$ gas fraction $\left(F_{\mathrm{NH}_{3}}=\right.$ the gaseous $\mathrm{NH}_{3}$ concentration divided by the sum of the gaseous $\mathrm{NH}_{3}$ and fine particulate $\mathrm{NH}_{4}^{+}$concentrations), where the concentrations are expressed in molar units. Monthly average partitioning for these reduced inorganic nitrogen forms from a nearby urban monitoring site, $10 \mathrm{~km}$ from the IAP tower, is plotted in Fig. S8. The $\mathrm{NH}_{3}$ gas fraction $\left(F_{\mathrm{NH}_{3}}\right)$ was found to be the highest in summer ( 0.83 in August) and the lowest in winter (0.36 in February). As expected, gas phase $\mathrm{NH}_{3}$ is favored in the warmer months, while particle phase $\mathrm{NH}_{4}^{+}$ is favored in the cooler months, with a gradual transition. Weekly $\mathrm{NH}_{4}^{+}$concentrations at the tower were estimated using weekly $\mathrm{NH}_{3}$ concentrations divided by monthly $F_{\mathrm{NH}_{3}}$, and WPSCF analysis of the sum of $\mathrm{NH}_{3}+\mathrm{NH}_{4}^{+}$was then performed (see results in Fig. S9). Results of this total WP$\mathrm{SCF}\left(\mathrm{NH}_{3}+\mathrm{NH}_{4}^{+}\right)$analysis yielded similar patterns to the $\mathrm{NH}_{3}$ WPSCF analysis for all heights and seasons, indicating the importance of the identified source regions for both the gaseous and particulate atmospheric forms of emitted $\mathrm{NH}_{3}$.

\section{Discussion}

\subsection{Vertical $\mathrm{NH}_{3}$ concentration profiles}

The North China Plain is a well-known "hotspot" for $\mathrm{NH}_{3}$ emissions due to the rapid development of industrialization, urbanization and intensive agriculture (Kang et al., 2016; Y. Zhang et al., 2010). In our study, high atmospheric $\mathrm{NH}_{3}$ concentrations $\left(13.3 \pm 4.8 \mu \mathrm{g} \mathrm{m}^{-3}\right)$ were found up to $320 \mathrm{~m}$ a.g.l. in urban Beijing (16 March 201616 March 2017), and were much higher than the average annual $\mathrm{NH}_{3}$ concentration $\left(3.3 \pm 1.4 \mu \mathrm{g} \mathrm{m}^{-3}\right)$ observed across a vertical profile at the $300 \mathrm{~m}$ rural BAO tower, USA (Li et al., 2017). Some studies of $\mathrm{NH}_{3}$ vertical distribution found that the $\mathrm{NH}_{3}$ concentration decreased significantly with height. For example, Tevlin et al. (2017) reported an overall in- 
Table 1. Overview of measured vertical $\mathrm{NH}_{3}$ concentrations $\left(\mu \mathrm{g} \mathrm{m}^{-3}\right)$ in previous studies and in this study.

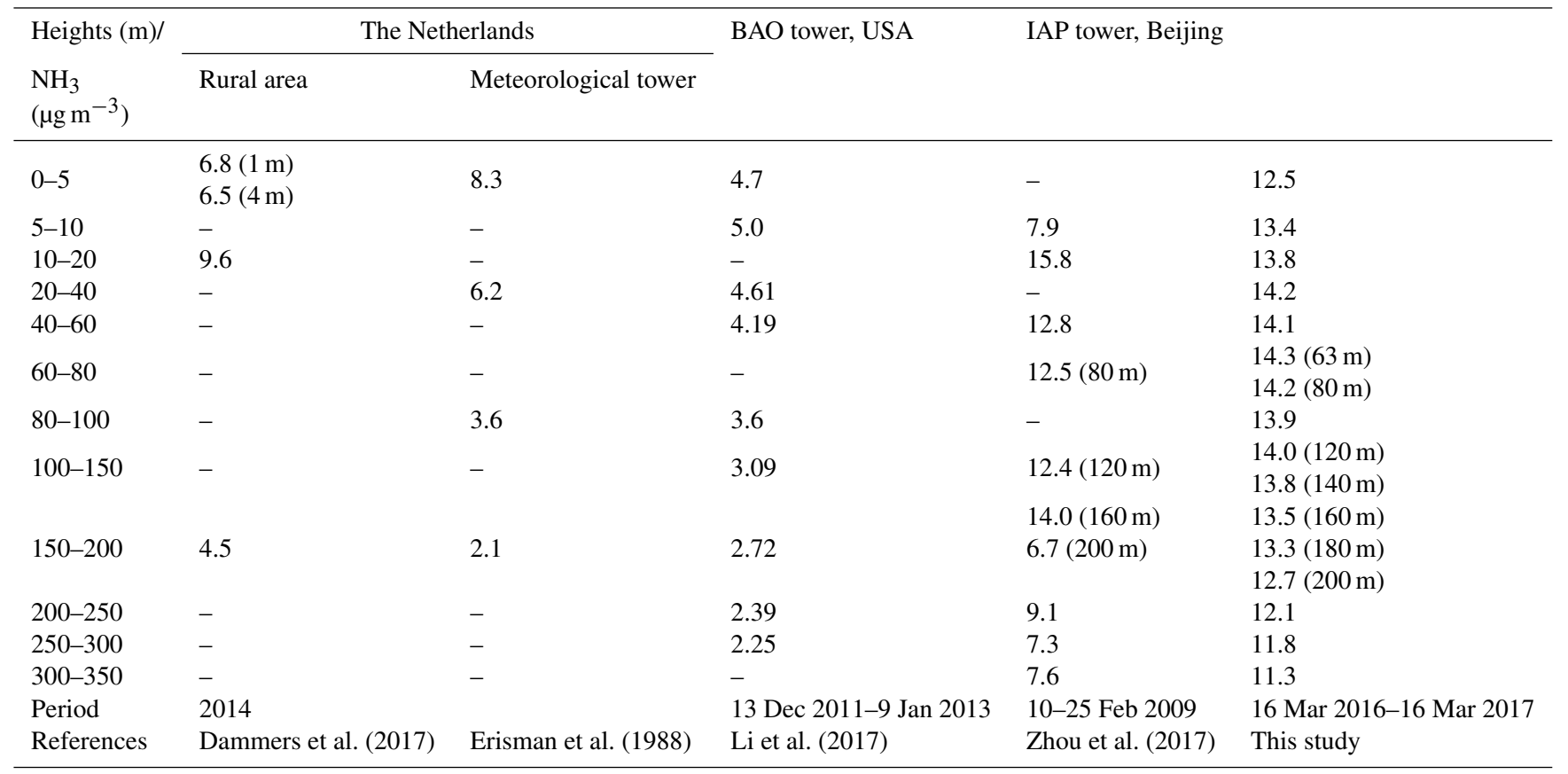

crease in summertime $\mathrm{NH}_{3}$ mixing ratios toward the surface of $6.7 \mathrm{ppb}$ or $5.1 \mu \mathrm{g} \mathrm{m}^{-3}(89 \%)$ during the day and $3.9 \mathrm{ppb}$ or $3.0 \mathrm{\mu g} \mathrm{m}^{-3}(141 \%)$ at night. In the BAO tower study (Li et al., 2017), which also measured concentrations using passive (Radiello) samplers deployed for 1- to 2-week sample periods, the concentration profiles showed a similar overall vertical distribution: the minimum $\mathrm{NH}_{3}$ concentration was observed at the top of the tower, it slowly increased towards a peak concentration at $\sim 10 \mathrm{~m}$, and a sharp reduction was then seen near the surface. By contrast, our results showed much smaller decreases in $\mathrm{NH}_{3}$ concentrations in the upper air in urban Beijing (Table 1), with only a $1.18 \mu \mathrm{g} \mathrm{m}^{-3}(9.5 \%)$ average decrease from the surface to the top of the tower (Fig. 3i). The flatter shape of the Beijing vertical profile may reflect a combination of strong local (e.g., vehicle) and regional (e.g., industrial and agricultural emissions) sources (Figs. 2 and 6) in our study, the fact that deep mixing layers regularly enveloped the full height of the tower within the surface boundary layer so that all sources influencing the tower measurements were vertically well mixed (Fig. S2), and/or the averaging of more distinct profiles over the week-long sample periods. In contrast to the "rural" boundary layer above the fields surrounding the BAO tower, the mixing in the Beijing urban area could be greatly enhanced by larger surface roughness (e.g., the average urban building height is $\sim 50 \mathrm{~m}$ ) and surface heating (Baklanov and Kuchin, 2004). Higher time resolution vertical profile measurements are needed in the future to untangle the influence of these potential factors.
Distinct seasonal variations in $\mathrm{NH}_{3}$ concentrations were found (Fig. 2), which were statistically most strongly associated with temperature rather than relative humidity or wind speed (Fig. S4). High temperatures enhance $\mathrm{NH}_{3}$ emissions from soil, applied fertilizers, animal waste, vertical mixing and increase volatilization of $\mathrm{NH}_{3}$ from $\mathrm{NH}_{4} \mathrm{NO}_{3}$ particulate matter (Bari et al., 2003; Ianniello et al., 2010; Li et al., 2014; Lin et al., 2006; Meng et al., 2011; Plessow et al., 2005; Walker et al., 2004; Zbieranowski and Aherne, 2012). While high (low) mixed-layer heights in spring and summer (autumn and winter) could dilute (concentrate) $\mathrm{NH}_{3}$ in the surface boundary layer (Fig. S3), average $\mathrm{NH}_{3}$ concentrations across the profile were actually high in summer/spring and low in winter/autumn, consistent with the strong temperature-driven seasonal variation of the $\mathrm{NH}_{3}$ concentration and the greater $\mathrm{NH}_{4} \mathrm{NO}_{3}$ particle formation during cold periods in autumn and winter. Conducting simultaneous measurements of fine particle composition at different heights in future studies would be valuable for more closely evaluating the influence of changes in phase-partitioning.

Li et al. (2017) found a vertical difference of approximately $75 \%$ from the concentration peak near the surface to the top of the BAO tower in winter (Fig. 3j), and attributed this strong vertical gradient to the occurrence of low level temperature inversions which trapped emissions closer to the surface during this period. During our study in Beijing, the vertical gradient was only $28 \%$ in winter (maximum concentration found at $32 \mathrm{~m}$ ), consistent with a deeper average boundary layer. However, inversions did limit the vertical mixing of $\mathrm{NH}_{3}$ during some periods in Beijing. 
Examination of the thermal inversion layer probability at 06:00 and 15:00 LT (Fig. S7b and c) revealed that $T$ inversions $\left(0.22 \pm 0.26^{\circ} \mathrm{C}\right)$ frequently occurred between 102 and $160 \mathrm{~m}$. Consequently, persistent higher $\mathrm{NH}_{3}$ concentrations begin at a lower altitude (Fig. S7a) as also observed by Tevlin et al. (2017). Because the time resolution of our Beijing study was one sample per week, we could not catch the changes between the daytime and nighttime $\mathrm{NH}_{3}$ vertical mixing. Compared to $\mathrm{NH}_{3}$ monitoring in real time (Tevlin et al., 2017), weekly sampling smooths diurnal vertical distributions and makes it harder to identify the influence of local surface sources or sinks.

Surfaces can act either as sources or sinks of $\mathrm{NH}_{3}$, depending on the surface $\mathrm{NH}_{3}$ content, ambient $\mathrm{NH}_{3}$ concentrations, and local meteorology and surface type (Tevlin et al., 2017; L. Zhang et al., 2010 ). The maximum $\mathrm{NH}_{3}$ concentration occurrence at $2 \mathrm{~m}$ in Beijing and the concentration decrease with increased height may reflect an important surface source of $\mathrm{NH}_{3}$, although our limited time resolution makes such conclusions tentative. The influence of the evaporation of dew/precipitation may also be important. Some studies found that dew is both a significant nighttime reservoir/sink and strong morning source of $\mathrm{NH}_{3}$ (Wentworth et al., 2016; Teng et al., 2017).

\subsection{Potential source analysis}

Areas south of Beijing with high WPSCF values appear to be important $\mathrm{NH}_{3}$ source regions (Fig. 6), suggesting regional transport from high agricultural $\mathrm{NH}_{3}$ emission areas (e.g., Hebei, Henan, Shandong provinces) contributed significantly to atmospheric $\mathrm{NH}_{3}$ in the Beijing urban region. Consistently higher $\mathrm{NH}_{3}$ concentrations were observed during periods with winds from the southeast, south and southwest at all heights, especially in summer (Fig. S6). Although $\mathrm{NH}_{3}$ has a limited atmospheric lifetime with respect to dry deposition, concentrations in these agricultural $\mathrm{NH}_{3}$ source regions can be extremely high (Shen et al., 2011) while significant $\mathrm{NH}_{3}$ can be tied up in longer-lived ammonium nitrate particles that partially dissociate to release $\mathrm{NH}_{3}$ back to the gas phase in response to $\mathrm{NH}_{3}$ loss by dry deposition (Ianniello et al., 2011; Kang et al., 2016; Xu et al., 2017). The WPSCF (Fig. 6) and $\mathrm{NH}_{3}$ emissions distribution (Fig. 1a) both suggest the importance not only of regional transport from nearby areas, but also the potential for local emissions to play an important role in sustaining the high $\mathrm{NH}_{3}$ level in Beijing, e.g., vehicular traffic (Chang et al., 2016; Pan et al., 2018a). As discussed above, stagnant meteorological conditions with low WS and $T$ inversions allow local emissions, such as those from urban traffic, to accumulate. Additionally, the topography of the mountains to the west and north of Beijing effectively traps polluted air over Beijing during southerly airflow, an effect reported in many Beijing particulate matter studies (Xia et al., 2016; Wu et al., 2009; Zhao et al., 2009).
Generally, $\mathrm{NH}_{3}$ source regions identified in the WPSCF analysis (Fig. 6) suggest that regional transport from the south exerts an important influence on Beijing $\mathrm{NH}_{3}$ concentrations throughout the year. The area south of Beijing (e.g., Hebei, Henan and Shandong provinces) is a hotspot of $\mathrm{NH}_{3}$ emission (Zhang et al., 2018), and half of $\mathrm{NH}_{3}$ emissions have been estimated to deposit as $\mathrm{NH}_{3}$ at urban sites in the North China Plain (Pan et al., 2018b). In addition, seasonal patterns of $\mathrm{NH}_{3}$ potential sources (Fig. 6) matched well with the seasonal surface $\mathrm{NH}_{3}$ concentrations in China (Zhang et al., 2018). In detail, $\mathrm{NH}_{3}$ concentrations were typically highest in summer, and south winds produced higher $\mathrm{NH}_{3}$ concentrations than other wind directions (Fig. S6). Spring and summer had a similar wind direction distribution (Fig. S6) and wind speeds (Fig. S5), but corresponding $\mathrm{NH}_{3}$ concentrations were lower in spring. This may reflect decreased emissions in regions to the south during cooler spring temperatures and the increased partitioning of $\mathrm{NH}_{3}$ into fine particles during this cooler season. As shown above aerosol-gas partitioning strongly influences $\mathrm{NH}_{3}$ concentrations; high $F_{\mathrm{NH}_{3}}$ during warm periods, especially summer, favored greater $\mathrm{NH}_{3}$ gas concentrations due to the thermodynamic tendency for $\mathrm{NH}_{4} \mathrm{NO}_{3}$ to dissociate to $\mathrm{NH}_{3}$ and $\mathrm{HNO}_{3}$ at high temperatures. Although $F_{\mathrm{NH}_{3}}$ was low in winter, indicating that $\mathrm{NH}_{4}^{+}$is the dominant $\mathrm{NH}_{x}$ form in this cold season, winter $\mathrm{NH}_{3}$ concentrations across all heights still averaged $8.3 \pm 2.6 \mathrm{\mu g} \mathrm{m}^{-3}$, with a similar wind direction distribution as other seasons, except at high altitudes (i.e., 240 and 320 m; Fig. S6).

\section{Conclusions and implications}

Our study is the first to continually monitor the vertical concentration profile of $\mathrm{NH}_{3}$ in urban Beijing. Weekly concentrations were measured for 1 year at 16 heights on the Beijing $325 \mathrm{~m}$ meteorological tower. The $\mathrm{NH}_{3}$ concentration averaged $13.3 \pm 4.8 \mu \mathrm{g} \mathrm{m}^{-3}$. The highest $\mathrm{NH}_{3}$ concentrations were always observed between heights of 32 and $63 \mathrm{~m}$, decreasing toward the surface and toward higher altitudes.

$\mathrm{NH}_{3}$ concentrations at all heights increased during warmer periods, consistent with increased $\mathrm{NH}_{3}$ emissions under warm conditions and the tendency for semivolatile ammonium nitrate to release $\mathrm{NH}_{3}$ to the gas phase. An analysis of the relationship between $\mathrm{NH}_{3}$ concentrations and local wind direction showed a tendency for higher concentrations during transport from regions to the south of Beijing; this was consistent with findings from the WPSCF analysis which showed that important source areas were mainly located to the south of Beijing: an area comprised of large agricultural regions and high $\mathrm{NH}_{3}$ emissions in the North China Plain. Local $\mathrm{NH}_{3}$ sources, such as urban traffic emissions, may also help account for the elevated $\mathrm{NH}_{3}$ concentrations $\left(>5 \mu \mathrm{g} \mathrm{m}^{-3}\right)$ observed even in periods when transport 
mostly came from the low $\mathrm{NH}_{3}$ mountainous regions to Beijing's north/northwest.

High $\mathrm{NH}_{3}$ concentrations in urban Beijing, from the surface up to $320 \mathrm{~m}$, the important role that $\mathrm{NH}_{3}$ plays in $\mathrm{PM}_{2.5}$ and haze formation, and the importance of regional transport of $\mathrm{NH}_{3}$ emissions from agricultural regions in neighboring provinces, suggest that future air quality improvement efforts should consider $\mathrm{NH}_{3}$ emission reductions and that the pollution controls should be jointly practiced at regional scales (e.g., the whole North China Plain) rather than only controlling local Beijing sources.

Data availability. Data used in this study are available from the corresponding author upon request (liu310@cau.edu.cn).

Supplement. The supplement related to this article is available online at: https://doi.org/10.5194/acp-18-16385-2018-supplement.

Author contributions. AT, YS and XL contributed to the conception and design of the experiments. YZ, DW and QW performed the experiments. YZ, AT, YS, XL, KB and JLCJ carried out the analysis of the data and wrote the paper. LZ, DL and YL discussed and offered the related supporting data for the paper.

Competing interests. The authors declare that they have no conflict of interest.

Acknowledgements. This work was supported by the State Key Research \& Development Programme (project nos. 2016YFC0207906, 2017YFC0210100, DQGG0208), the National Natural Science Foundation of China (project nos. 41425007, 91744207) and the National Postdoctoral Program for Innovative Talents (grant no. BX201600157).

Edited by: John Liggio

Reviewed by: two anonymous referees

\section{References}

Ashbaugh, L. L., Malm, W. C., and Sadeh, W. Z.: A residence time probability analysis of sulfur concentrations at Grand Canyon National Park, Atmos. Environ., 19, 1263-1270, https://doi.org/10.1016/0004-6981(85)90256-2, 1985.

Baklanov, A. and Kuchin, A.: The mixing height in urban areas: comparative study for Copenhagen, Atmos. Chem. Phys. Discuss., 4, 2839-2866, https://doi.org/10.5194/acpd-4-2839-2004, 2004.

Bari, A., Ferraro, V., Wilson, L. R., Luttinger, D., and Husain, L.: Measurements of gaseous $\mathrm{HONO}, \mathrm{HNO}_{3}, \mathrm{SO}_{2}, \mathrm{HCl}, \mathrm{NH}_{3}$, particulate sulfate and $\mathrm{PM}_{2.5}$ in New York, NY, Atmos. Environ.,
37, 2825-2835, https://doi.org/10.1016/S1352-2310(03)001997, 2003.

Beijing Transport Institute: Annual report of Beijing traffic development in http://www.bjtrc.org.cn/JGJS.aspx?id=5.2\&Menu= GZCG (last access: 14 November 2018), 2017.

Chang, Y., Liu, X., Deng, C., Dore, A. J., and Zhuang, G.: Source apportionment of atmospheric ammonia before, during, and after the 2014 APEC summit in Beijing using stable nitrogen isotope signatures, Atmos. Chem. Phys., 16, 11635-11647, https://doi.org/10.5194/acp-16-11635-2016, 2016.

Dammers, E., Schaap, M., Haaima, M., Palm, M., Kruit, R. W., Volten, H., Hensen, A., Swart, D., and Erisman, J.: Measuring atmospheric ammonia with remote sensing campaign: Part 1 - Characterisation of vertical ammonia concentration profile in the centre of The Netherlands, Atmos. Environ., 169, 97-112, https://doi.org/10.1016/j.atmosenv.2017.08.067, 2017.

EMEP Webdab emission data hosted by the Centre on Emission Inventories and Projections (CEIP): http://www.ceip.at, last access: 20 August 2018.

Erisman, J. W., Vermetten, A. W., Asman, W. A., WaijersIjpelaan, A., and Slanina, J.: Vertical distribution of gases and aerosols: the behaviour of ammonia and related components in the lower atmosphere, Atmos. Environ., 22, 1153-1160, https://doi.org/10.1016/0004-6981(88)90345-9, 1988.

Erisman, J. W., Sutton, M. A., Galloway, J., Klimont, Z., and Winiwarter, W.: How a century of ammonia synthesis changed the world, Nat. Geosci., 1, 636-639, https://doi.org/10.1038/ngeo325, 2008.

Fowler, D., Pilegaard, K., Sutton, M., Ambus, P., Raivonen, M., Duyzer, J., Simpson, D., Fagerli, H., Fuzzi, S., and Schjørring, J. K.: Atmospheric composition change: ecosystemsatmosphere interactions, Atmos. Environ., 43, 5193-5267, https://doi.org/10.1016/j.atmosenv.2009.07.068, 2009.

Fu, X., Wang, S., Xing, J., Zhang, X., Wang, T., and Hao, J.: Increasing Ammonia Concentrations Reduce the Effectiveness of Particle Pollution Control Achieved via $\mathrm{SO}_{2}$ and $\mathrm{NO}_{x}$ Emissions Reduction in East China, Environ. Sci. Technol. Lett., 4, 221227, https://doi.org/10.1021/acs.estlett.7b00143, 2017.

Galloway, J. N., Aber, J. D., Erisman, J. W., Seitzinger, S. P., Howarth, R. W., Cowling, E. B., and Cosby, B. J.: The nitrogen cascade, AIBS Bulletin, 53, 341-356, https://doi.org/10.1641/00063568(2003)053[0341:TNC]2.0.CO;2, 2003

Gu, B., Ge, Y., Ren, Y., Xu, B., Luo, W., Jiang, H., Gu, B., and Chang, J.: Atmospheric reactive nitrogen in China: Sources, recent trends, and damage costs, Environ. Sci. Technol., 46, 9420 9427, https://doi.org/10.1021/es301446g, 2012.

Gu, B., Sutton, M. A., Chang, S. X., Ge, Y., and Chang, J.: Agricultural ammonia emissions contribute to China's urban air pollution, Front. Ecol. Environ., 12, 265-266, https://doi.org/10.1890/14.WB.007, 2014.

Guo, S., Hu, M., Zamora, M. L., Peng, J., Shang, D., Zheng, J., Du, Z., Wu, Z., Shao, M., and Zeng, L.: Elucidating severe urban haze formation in China, P. Natl. Acad. Sci. USA, 111, 17373-17378, https://doi.org/10.1073/pnas.1419604111, 2014.

Huang, R., Zhang, Y., Bozzetti, C., Ho, K., Cao, J., Han, Y., Daellenbach, K. R., Slowik, J. G., Platt, S. M., and Canonaco, F.: High secondary aerosol contribution to particulate pol- 
lution during haze events in China, Nature, 514, 218-222, https://doi.org/10.1038/nature13774, 2014.

Ianniello, A., Spataro, F., Esposito, G., Allegrini, I., Rantica, E., Ancora, M., Hu, M., and Zhu, T.: Occurrence of gas phase ammonia in the area of Beijing (China), Atmos. Chem. Phys., 10, 9487-9503, https://doi.org/10.5194/acp-10-9487-2010, 2010.

Ianniello, A., Spataro, F., Esposito, G., Allegrini, I., Hu, M., and Zhu, T.: Chemical characteristics of inorganic ammonium salts in $\mathrm{PM}_{2.5}$ in the atmosphere of Beijing (China), Atmos. Chem. Phys., 11, 10803-10822, https://doi.org/10.5194/acp-11-108032011, 2011.

Kang, Y., Liu, M., Song, Y., Huang, X., Yao, H., Cai, X., Zhang, H., Kang, L., Liu, X., and Yan, X.: High-resolution ammonia emissions inventories in China from 1980 to 2012, Atmos. Chem. Phys., 16, 2043-2058, https://doi.org/10.5194/acp16-2043-2016, 2016.

Klimont, Z.: Current and Future Emissions of Ammonia in China, 10th annual emission inventory conference: one atmosphere, One inventory, many challenges, 1-3 May 2001, Denver, CO, 2001.

Lee, D., Dollard, G., Derwent, R., and Pepler, S.: Observations on gaseous and aerosols components of the atmosphere and their relationships, Water Air Soil Pollut., 113, 175-202, https://doi.org/10.1023/A:1005024410887, 1999.

Li, P., Yan, R., Yu, S., Wang, S., Liu, W., and Bao, H.: Reinstate regional transport of $\mathrm{PM}_{2.5}$ as a major cause of severe haze in Beijing, P. Natl. Acad. Sci. USA, 112, E2739-E2740, https://doi.org/10.1073/pnas.1502596112, 2015.

Li, Y., Schwandner, F. M., Sewell, H. J., Zivkovich, A., Tigges, M., Raja, S., Holcomb, S., Molenar, J. V., Sherman, L., and Archuleta, C.: Observations of ammonia, nitric acid, and fine particles in a rural gas production region, Atmos. Environ., 83, 80-89, https://doi.org/10.1016/j.atmosenv.2013.10.007, 2014.

Li, Y., Thompson, T. M., Damme, M. V., Chen, X., Benedict, K. B., Shao, Y., Day, D., Boris, A., Sullivan, A. P., and Ham, J.: Temporal and spatial variability of ammonia in urban and agricultural regions of northern Colorado, United States, Atmos. Chem. Phys., 17, 6197-6213, https://doi.org/10.5194/acp17-6197-2017, 2017.

Lin, Y., Cheng, M., Ting, W., and Yeh, C.: Characteristics of gaseous $\mathrm{HNO}_{2}, \mathrm{HNO}_{3}, \mathrm{NH}_{3}$ and particulate ammonium nitrate in an urban city of Central Taiwan, Atmos. Environ., 40, 47254733, https://doi.org/10.1016/j.atmosenv.2006.04.037, 2006.

Liu, X., Zhang, Y., Han, W., Tang, A., Shen, J., Cui, Z., Vitousek, P., Erisman, J. W., Goulding K., Christie, P., Fangmeier, A., and Zhang, F.: Enhanced nitrogen deposition over China, Nature, 494, 459-462, https://doi.org/10.1038/nature11917, 2013.

Meng, Z., Lin, W., Jiang, X., Yan, P., Wang, Y., Zhang, Y., Jia, X., and Yu, X.: Characteristics of atmospheric ammonia over Beijing, China, Atmos. Chem. Phys. , 11, 6139-6151, https://doi.org/10.5194/acp-11-6139-2011, 2011.

Öztürk, F., Bahreini, R., Wagner, N., Dubé, W., Young, C., Brown, S., Brock, C., Ulbrich, I., Jimenez, J., and Cooper, O.: Vertically resolved chemical characteristics and sources of submicron aerosols measured on a Tall Tower in a suburban area near Denver, Colorado in winter, J. Geophys. Res.-Atmos., 118, 1359113605, https://doi.org/10.1002/2013JD019923, 2013.

Pan, Y., Tian, S., Liu, D., Fang, Y., Zhu, X., Gao, M., Gao, J., Michalski, G., and Wang, Y.: Isotopic evidence for enhanced fossil fuel sources of aerosol ammonium in the urban atmosphere, Environ. Pollut., 238, 942-947, https://doi.org/10.1016/j.envpol.2018.03.038, 2018a.

Pan, Y., Tian, S., Zhao, Y., Zhang, L., Zhu, X., Gao, J., Huang, W., Zhou, Y., Song, Y., and Zhang, Q.: Identifying ammonia hotspots in China using a national observation network, Environ. Sci. Technol., 52, 3926-3934, https://doi.org/10.1021/acs.est.7b05235, 2018b.

Plessow, K., Spindler, G., Zimmermann, F., and Matschullat, J.: Seasonal variations and interactions of $\mathrm{N}$ containing gases and particles over a coniferous forest, Saxony, Germany, Atmos. Environ., 39, 6995-7007, https://doi.org/10.1016/j.atmosenv.2005.07.046, 2005.

Polissar, A., Hopke, P., Paatero, P., Kaufmann, Y., Hall, D., Bodhaine, B., Dutton, E., and Harris, J.: The aerosol at Barrow, Alaska: long-term trends and source locations, Atmos. Environ., 33, 2441-2458, https://doi.org/10.1016/S1352-2310(98)004233, 1999.

Quan, J., Gao, Y., Zhang, Q., Tie, X., Cao, J., Han, S., Meng, J., Chen, P., and Zhao, D.: Evolution of planetary boundary layer under different weather conditions, and its impact on aerosol concentrations, Particuology, 11, 34-40, https://doi.org/10.1016/j.partic.2012.04.005, 2013.

Reis, S., Pinder, R., Zhang, M., Lijie, G., and Sutton, M.: Reactive nitrogen in atmospheric emission inventories, Atmos. Chem. Phys., 9, 7657-7677, https://doi.org/10.5194/acp-9-7657-2009, 2009.

Riedel, T. P., Wagner, N. L., Dubé, W. P., Middlebrook, A. M., Young, C. J., Öztürk, F., Bahreini, R., VandenBoer, T. C., Wolfe, D. E., and Williams, E. J.: Chlorine activation within urban or power plant plumes: Vertically resolved $\mathrm{ClNO}_{2}$ and $\mathrm{Cl}_{2}$ measurements from a tall tower in a polluted continental setting, J. Geophys. Res.-Atmos., 118, 8702-8715, https://doi.org/10.1002/jgrd.50637, 2013.

Shen, J., Liu, X., Zhang, Y., Fangmeier, A., Goulding, K., and Zhang, F.: Atmospheric ammonia and particulate ammonium from agricultural sources in the North China Plain, Atmos. Environ., 45, 5033-5041, https://doi.org/10.1016/j.atmosenv.2011.02.031, 2011.

Shephard, M. and Cady-Pereira, K.: Cross-track Infrared Sounder (CrIS) satellite observations of tropospheric ammonia, Atmos. Meas. Tech., 8, 1323-1336, https://doi.org/10.5194/amt8-1323-2015, 2015.

Sun, K., Tao, L., Miller, D. J., Zondlo, M. A., Shonkwiler, K. B., Nash, C., and Ham, J. M.: Open-path eddy covariance measurements of ammonia fluxes from a beef cattle feedlot, Agr. Forest Meteorol., 213, 193-202, https://doi.org/10.1016/j.agrformet.2015.06.007, 2015.

Sun, K., Tao, L., Miller, D. J., Pan, D., Golston, L. M., Zondlo, M. A., Griffin, R. J., Wallace, H. W., Leong, Y. J., and Yang, M. M.: Vehicle emissions as an important urban ammonia source in the United States and China, Environ. Sci. Technol., 51, 2472-2481, https://doi.org/10.1021/acs.est.6b02805, 2017.

Sun, Y., Jiang, Q., Wang, Z., Fu, P., Li, J., Yang, T., and Yin, Y.: Investigation of the sources and evolution processes of severe haze pollution in Beijing in January 2013, J. Geophys. Res.-Atmos., 119, 4380-4398, https://doi.org/10.1002/2014JD021641, 2014.

Sun, Y., Du, W., Fu, P., Wang, Q., Li, J., Ge, X., Zhang, Q., Zhu, C., Ren, L., and Xu, W.: Primary and secondary aerosols in Beijing in winter: sources, variations and processes, Atmos. 
Chem. Phys., 16, 8309-8329, https://doi.org/10.5194/acp-168309-2016, 2016.

Sutton, M. A., Erisman, J. W., Dentener, F., and Möller, D.: Ammonia in the environment: from ancient times to the present, Environ. Pollut., 156, 583-604, https://doi.org/10.1016/j.envpol.2008.03.013, 2008.

Tang, G., Zhu, X., Hu, B., Xin, J., Wang, L., Münkel, C., Mao, G., and Wang, Y.: Impact of emission controls on air quality in Beijing during APEC 2014: lidar ceilometer observations, Atmos. Chem. Phys., 15, 12667-12680, https://doi.org/10.5194/acp-1512667-2015, 2015

Tang, Y. S., Cape, J. N., and Sutton, M. A.: Development and types of passive samplers for monitoring atmospheric $\mathrm{NO}_{2}$ and $\mathrm{NH}_{3}$ concentrations, Scient. World J., 1, 513-529, https://doi.org/10.1100/tsw.2001.82, 2014.

Teng, X., Hu, Q., Zhang, L., Qi, J., Shi, J., Xie, H., Gao, H., and Yao, X.: Identification of major sources of atmospheric $\mathrm{NH}_{3}$ in an urban environment in northern China during wintertime, Environ. Sci. Technol., 51, 6839-6848, https://doi.org/10.1021/acs.est.7b00328, 2017.

Tevlin, A., Li, Y., Collett, J., McDuffie, E., Fischer, E., and Murphy, J.: Tall tower vertical profiles and diurnal trends of ammonia in the Colorado Front Range, J. Geophys. Res.-Atmos., 122, 12468-12487, https://doi.org/10.1002/2017JD026534, 2017.

USEPA: Air Pollutant Emissions Trends Data, https://www.epa.gov/air-emissions-inventories/ air-pollutant-emissions-trends-data, last access: 15 October 2018.

Van Damme, M., Clarisse, L., Dammers, E., Liu, X., Nowak, J., Clerbaux, C., Flechard, C., Galy-Lacaux, C., Xu, W., and Neuman, J.: Towards validation of ammonia $\left(\mathrm{NH}_{3}\right)$ measurements from the IASI satellite, Atmos. Meas. Tech., 8, 1575-1591, https://doi.org/10.5194/amt-8-1575-2015, 2015

VandenBoer, T. C., Brown, S. S., Murphy, J. G., Keene, W. C., Young, C. J., Pszenny, A., Kim, S., Warneke, C., Gouw, J. A., and Maben, J. R.: Understanding the role of the ground surface in $\mathrm{HONO}$ vertical structure: High resolution vertical profiles during NACHTT-11, J. Geophys. Res.-Atmos., 118, 10155-10171, https://doi.org/10.1002/jgrd.50721, 2013.

Vogt, E., Held, A., and Klemm, O.: Sources and concentrations of gaseous and particulate reduced nitrogen in the city of Münster (Germany), Atmos. Environ., 39, 7393-7402, https://doi.org/10.1016/j.atmosenv.2005.09.012, 2005.

Walker, J., Whitall, D. R., Robarge, W., and Paerl, H. W.: Ambient ammonia and ammonium aerosol across a region of variable ammonia emission density, Atmos. Environ., 38, 1235-1246, https://doi.org/10.1016/j.atmosenv.2003.11.027, 2004.

Wang, S., Xing, J., Jang, C., Zhu, Y., Fu, J. S., and Hao, J.: Impact assessment of ammonia emissions on inorganic aerosols in East China using response surface modeling technique, Environ. Sci. Technol., 45, 9293-9300, https://doi.org/10.1021/es2022347, 2011.

Wang, S., Nan, J., Shi, C., Fu, Q., Gao, S., Wang, D., Cui, H., SaizLopez, A., and Zhou, B.: Atmospheric ammonia and its impacts on regional air quality over the megacity of Shanghai, China, Sci. Rep., 5, 15842, https://doi.org/10.1038/srep15842, 2015.

Wang, Y.: MeteoInfo: GIS software for meteorological data visualization and analysis, Meteorol. Appl., 21, 360-368, https://doi.org/10.1002/met.1345, 2014.
Wentworth, G. R., Murphy, J. G., Benedict, K. B., Bangs, E. J., and Collett Jr., J. L.: The role of dew as a night-time reservoir and morning source for atmospheric ammonia, Atmos. Chem. Phys., 16, 7435-7449, https://doi.org/10.5194/acp-167435-2016, 2016.

Wiegner, M., Emeis, S., Freudenthaler, V., Heese, B., Junkermann, W., Münkel, C., Schäfer, K., Seefeldner, M., and Vogt, S.: Mixing layer height over Munich, Germany: Variability and comparisons of different methodologies, J. Geophys. Res.-Atmos., 111, D13201, https://doi.org/10.1029/2005JD006593, 2006.

Wu, Y., Gu, B., Erisman, J. W., Reis, S., Fang, Y., Lu, X., and Zhang, X.: $\mathrm{PM}_{2.5}$ pollution is substantially affected by ammonia emissions in China, Environ. Pollut., 218, 86-94, https://doi.org/10.1016/j.envpol.2016.08.027, 2016.

Wu, Z., Hu, M., Shao, K., and Slanina, J.: Acidic gases, $\mathrm{NH}_{3}$ and secondary inorganic ions in $\mathrm{PM}_{10}$ during summertime in Beijing, China and their relation to air mass history, Chemosphere, 76, 1028-1035, https://doi.org/10.1016/j.chemosphere.2009.04.066, 2009.

Xia, Y., Zhao, Y., and Nielsen, C. P.: Benefits of China's efforts in gaseous pollutant control indicated by the bottom-up emissions and satellite observations 2000-2014, Atmos. Environ., 136, 43 53, https://doi.org/10.1016/j.atmosenv.2016.04.013, 2016.

Xu, W., Luo, X., Pan, Y. , Zhang, L., Tang, A., Shen, J., Zhang, Y., Li, K., Wu, Q., Yang, D., Zhang, Y., Xue, J., Li, W., Li, Q., Tang, L., Lu, S., Liang, T., Tong, Y., Liu, P., Zhang, Q., Xiong, Z., Shi, X., Wu, L., Shi, W., Tian, K., Zhong, X., Shi, K., Tang, Q., Zhang, L., Huang, J., He, C., Kuang, F., Zhu, B., Liu, H., Jin, X., Xin, Y., Shi, X., Du, E., Dore, A. J., Tang, S., Collett Jr., J. L., Goulding, K., Sun, Y., Ren, J., Zhang, F., and Liu, X.: Quantifying atmospheric nitrogen deposition through a nationwide monitoring network across China, Atmos. Chem. Phys., 15, 1234512360, https://doi.org/10.5194/acp-15-12345-2015, 2015.

Xu, W., Song, W., Zhang, Y., Liu, X., Zhang, L., Zhao, Y., Liu, D., Tang, A., Yang, D., Wang, D., Wen, Z., Pan, Y., Fowler, D., Collett Jr., J. L., Erisman, J. W., Goulding, K., Li, Y., and Zhang, F.: Air quality improvement in a megacity: implications from 2015 Beijing Parade Blue pollution control actions, Atmos. Chem. Phys., 17, 31-46, https://doi.org/10.5194/acp-17-31-2017, 2017.

Yamamoto, N., Kabeya, N., Onodera, M., Takahahi, S., Komori, Y., Nakazuka, E., and Shirai, T.: Seasonal variation of atmospheric ammonia and particulate ammonium concentrations in the urban atmosphere of Yokohama over a 5-year period, Atmos. Environ., 22, 2621-2623, https://doi.org/10.1016/0004-6981(88)90498-2, 1988.

Yamamoto, N., Nishiura, H., Honjo, T., Ishikawa, Y., and Suzuki, $\mathrm{K}$.: A long-term study of atmospheric ammonia and particulate ammonium concentrations in Yokohama, Japan, Atmos. Environ., 29, 97-103, https://doi.org/10.1016/1352-2310(94)00226B, 1995.

Yang, F., Tan, J., Zhao, Q., Du, Z., He, K., Ma, Y., Duan, F., Chen, G., and Zhao, Q.: Characteristics of $\mathrm{PM}_{2.5}$ speciation in representative megacities and across China, Atmos. Chem. Phys., 11, 5207-5219, https://doi.org/10.5194/acp-11-5207-2011, 2011.

Ye, X., Ma, Z., Zhang, J., Du, H., Chen, J., Chen, H., Yang, X., Gao, W., and Geng, F.: Important role of ammonia on haze formation in Shanghai, Environ. Res. Lett., 6, 024019, https://doi.org/10.1088/1748-9326/6/2/024019, 2011. 
Zbieranowski, A. L. and Aherne, J.: Spatial and temporal concentration of ambient atmospheric ammonia in southern Ontario, Canada, Atmos. Environ., 62, 441-450, https://doi.org/10.1016/j.atmosenv.2012.08.041, 2012.

Zhang, L., Wright, L., and Asman, W.: Bi-directional air-surface exchange of atmospheric ammonia: A review of measurements and a development of a big-leaf model for applications in regionalscale air-quality models, J. Geophys. Res.-Atmos., 115, D20310, https://doi.org/10.1029/2009JD013589, 2010.

Zhang, L., Chen, Y., Zhao, Y., Henze, D. K., Zhu, L., Song, Y., Paulot, F., Liu, X., Pan, Y., and Lin, Y.: Agricultural ammonia emissions in China: reconciling bottom-up and top-down estimates, Atmos. Chem. Phys., 18, 339-355, https://doi.org/10.5194/acp-18-339-2018, 2018.

Zhang, Q., Streets, D. G., Carmichael, G. R., He, K., Huo, H., Kannari, A., Klimont, Z., Park, I. S., Reddy, S., Fu, J., Chen, D., Duan, L., Lei, Y., Wang, L., and Yao, Z.: Asian emissions in 2006 for the NASA INTEX-B mission, Atmos. Chem. Phys., 9, 51315153, https://doi.org/10.5194/acp-9-5131-2009, 2009.

Zhang, X., Wu, Y., Liu, X., Reis, S., Jin, J., Dragosits, U., Damme, M. V., Clarisse, L., Whitburn, S., Coheur, P. F., and $\mathrm{Gu}$, B.: Ammonia emissions may be substantially underestimated in China, Environ. Sci. Technol., 51, 12089-12096, https://doi.org/10.1021/acs.est.7b02171, 2017.
Zhang, Y., Dore, A. J., Ma, L., Liu, X., Ma, W., Cape, J. N., and Zhang, F.: Agricultural ammonia emissions inventory and spatial distribution in the North China Plain, Environ. Pollut., 158, 490501, https://doi.org/10.1016/j.envpol.2009.08.033, 2010.

Zhao, D. and Wang, A.: Estimation of anthropogenic ammonia emissions in Asia, Atmos. Environ., 28, 689-694, https://doi.org/10.1016/1352-2310(94)90045-0, 1994.

Zhao, X., Zhang, X., Xu, X., Xu, J., Meng, W., and Pu, W.: Seasonal and diurnal variations of ambient $\mathrm{PM}_{2.5}$ concentration in urban and rural environments in Beijing, Atmos. Environ., 43, 28932900, https://doi.org/10.1016/j.atmosenv.2009.03.009, 2009.

Zheng, G., Duan, F., Su, H., Ma, Y., Cheng, Y., Zheng, B., Zhang, Q., Huang, T., Kimoto, T., Chang, D., Pöschl, U., Cheng, Y., and He, K.: Exploring the severe winter haze in Beijing: the impact of synoptic weather, regional transport and heterogeneous reactions, Atmos. Chem. Phys., 15, 2969-2983, https://doi.org/10.5194/acp-15-2969-2015, 2015.

Zhou, Y., Zhu, X., Pan, Y., Tian, S., Liu, Q., Sun, Y., An, J., and Wang, Y.: Vertical distribution of gaseous pollutants in the lower atmospheric boundary layer in urban Beijing, Environ. Chem., 36, 1752-1759, 2017. 